\section{Some properties of ayran fortified with black carrot powder}

\begin{abstract}
Ayran is a traditional salty drinkable fermented product. Black carrot is well known and very rich source of anthocyanins and combining with ayran was obtained a product that is natural, nutritious and highly attractive for consumer. In this study investigated the composition and antioksidant activity of the ayran fortified with black carrot powder. Black carrots were dried and powdered by freeze drying method and four batches of ayrans were manufactured by adding dried black carrots powder into the milk at increasing rates. One batch was treated as a control sample without black carrot powder addition and three batches of ayrans were manufactured by adding black carrot powder at the rates of $0.25 \%, 0.5 \%$ and $1 \%$. All of the samples were pasteurized at $90^{\circ} \mathrm{C}$ for 5 minutes. Following the pasteurization, milks were cooled to $46 \pm 1^{\circ} \mathrm{C}$ and then inoculated with starter culture. Inoculated milks were incubated until the $\mathrm{pH}$ became 4.6-4.7. Ayran samples were cooled down and $0.5 \%$ salt was added. The mixture was homogenized and filled into $200 \mathrm{~g}$ of cups and stored at $4{ }^{\circ} \mathrm{C}$ before analyses. At the 5th and 20th minutes, the lowest antioxidant activity values were found to be $5.88 \%$ and $6.08 \%$ for control sample, while the highest antioxidant activity values were found $19.90 \%$ and $21.6 \%$ for ayran with $1 \%$ black carrot powder. Increasing concentrations of added black carrot into the milk, resulted higher antioxidant activity in ayran as determined by DPPH method $(\mathrm{p}<0.05)$. However, $\mathrm{pH}$, dry matter, fat, protein and salt contents of the ayran samples were not influenced by black carrot powder addition $(\mathrm{p}>0.05)$.
\end{abstract}

Key words: Ayran, black carrot, antioxidant activity, composition.

\section{Siyah havuç tozu ile zenginleştirilmiş ayranın bazı özellikleri}

Özet

Ayran, geleneksel tuzlu içilebilir fermente bir süt ürünüdür. Siyah havuç çok zengin antosiyanin kaynağı olarak bilinir ve ayran ile bir araya gelerek tüketici için doğal, besleyici ve albenisi yüksek bir ürün elde edilmiştir. $\mathrm{Bu}$ çalışmada, siyah havuç tozu ile zenginleştirilmiş ayranın bileşimi ve antioksidan aktivitesi incelenmiştir. Siyah havuçlar dondurarak kurutma yöntemi ile kurutulup toz haline getirilmiş ve süte farklı oranlarda ilave edilerek dört grup ayran üretilmiştir. Bir grup, siyah havuç tozu ilavesi olmaksızın kontrol numunesi olarak ayrılmıştır ve üç grup ayrana $\% 0.25, \% 0.5$ ve $\% 1$ oranlarında siyah havuç tozu ilave edilmiştir. Örneklerin tamam $190^{\circ} \mathrm{C}$ de 5 dakika pastörize edilmiştir. Pastörizasyonun ardından, sütler $46 \pm 1^{\circ} \mathrm{C}^{\prime}$ ye soğutulmuş, starter kültür ilavesi yapılmış ve $\mathrm{pH}$ 4.6-4.7 olana kadar inkübasyona bırakılmıştır. Ayran örnekleri soğutulmuş ve \%0.5 oranında tuz ilave edilmiştir. Karışım homojen hale getirilmiş, $200 \mathrm{~g}$ bardaklara doldurulmuş ve analizleri yapılıncaya kadar $4^{\circ} \mathrm{C}^{\prime}$ de depolanmıştır. 5. ve 20. dakikalarda, en düşük antioksidan aktivite değerleri kontrol numunesi için $\% 5.88$ ve $\% 6.08$ iken, en yüksek antioksidan aktivite değerleri \%1 havuç tozu ilaveli ayran için \%19.90 ve \%21.6 olarak bulunmuştur. Siyah havucun artan oranlarda ilavesi ayranın DPPH yöntemi ile belirlenen antioksidan aktivitesini artırmıştır $(\mathrm{p}<0.05)$. Bununla birlikte, ayran örneklerinin $\mathrm{pH}$, kurumadde, yağ, protein ve tuz değerleri siyah havuç tozu ilavesinden etkilenmemiştir ( $\mathrm{p}>0.05)$.

Anahtar kelimeler: Ayran, siyah havuç, antioksidan aktivite, bileşim.
Araştırma Makalesi

\section{Dilek SAY ${ }^{1}$ \\ İbrahim Başar SAYDAM ${ }^{2}$ Nuray GÜZELER ${ }^{2}$}

${ }^{1}$ Vocational School of Pozanti, Cukurova University, Adana, Turkey

${ }^{2}$ Departmant of Food Engineering, Faculty of Agriculture, Cukurova University, Adana, Turkey

İlgili yazar

(Corresponding Author)

Dr. Öğr. Üyesi Dilek SAY

Cukurova University, Vocational School

of Pozant

Zafer Mah. Şehit Esat Körkün Sok. No:

3/A, Pozant1, Adana/Turkey

(https://pozantimyo.cu.edu.tr/tr/)

dsay@cu.edu.tr (mailto:dsay@cu.edu.tr)

Makale Bilgisi

Geliş: 20-12-2018

Kabul: 28-12-2018

https://dx.doi.org/10.31797/vetbio.499749

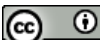

This work is licensed under a Creative Commons Attribution 4.0 International License

Say, D., Saydam, İ.B., Güzeler, N. (2018). Some properties of ayran fortified with black carrot powder J Adv VetBio Sci Tech. 3(3): 54-60. DOI: 10.31797/vetbio.499749 


\section{Introduction}

Ayran (drinking yogurt) is one of the traditional fermented milk beverage which has a distinctive salty taste in Turkey. It is also known as "Dough" in Iran, "Tan" in Armenia, "Laban Ayran" in Syria and Lebanon, "Shenina" in Jordan, "Moru" in South India, "Laban Arbil" in Iraq and "Ayrani" in Cyprus (Y1ld1z, 2010). Ayran is prepared by addition of water to yogurt or by the addition of yogurt culture (Streptococcus thermophilus and L. delbrueckii subsp. bulgaricus) to standardized milk according to Turkish Food Codex (Anonymous, 2009). The shelf life of ayran is reported as $10-15$ days at $4^{\circ} \mathrm{C}$ by the manufacturers (Ayar and Burucu, 2013). Ayran is very rich in point of electrolytes. In this respect, it is very important for replacing lost water and minerals of body by sweating especially in hot summer days (Tamuçay-Özünlü ve Koçak, 2010a). It is estimated that ayran consumption in Turkey is ca. 1 million ton annually (Koçak and Avşar, 2010).

Some fruits and vegetables contain colourful compounds that may reduce the risk of diseases initiated by free radicals. This compounds with antioxidant properties also include polyphenols, such as anthocyanins (Witrowa-Rajchert et al., 2009). Black carrot (Daucus carota L.) is a root-vegetable which is known as a very rich source of anthocyanins (Uyan et.al., 2004). Apart from imparting attractiveness to food, anthocyanins also have healthpromoting benefits as they can be used for treating various illnesses via their pharmacological properties (Kong et.al., 2003). In the black carrot, five basic anthocyanins and three non-anthocyanin basic phenolic substances were identified, and the most important phenolic substance was found to be chlorogenic acid. It has also been reported that the antioxidant activity of black carrot originates from its high content of chlorogenic acid (Özkan, 2009; Sharma et.al., 2012).

Freeze drying is one of the most advanced drying methods. Because freeze drying is carried out at low temperatures, the temperature-sensitive biological components of the food are protected from damage. The color, structure, flavor and rehydration characteristics of freeze-dried food products in this respect are superior to those of the dried products by other drying method (Krokida ve Philippopoulos, 2006).
No studies have been found on the freeze dried of black carrots and additions to ayran. In this study, it is aimed to increase the nutritional and functional properties of ayran with adding black carrot powder and to evaluate an effective and suitable utilization of black carrot in ayran production. Therefore, the composition and antioxidant activity of the ayran samples were investigated.

\section{Material and methods}

\section{Materials}

Raw cow's milk used in the production of ayran was provided from Animal Husband section of Cukurova University, Faculty of Agriculture, Adana, Turkey. Lyophilized ayran starter cultures of YO-MIX 496 ( $S$. thermophilus / L. delbruckii subsp. bulgaricus) was obtained from Danisco Deutschland GmbH, Niebüll, Germany. Sterilized halite was used as salt. Black carrots were supplied from Konya, Turkey. $200 \mathrm{ml}$ polystyrene cups with aluminum foil cover were used as packaging material.

\section{Methods}

\section{Freeze dried black carrot}

The black carrots brought to the laboratory were washed and then chopped in circles about $0.5 \mathrm{~cm}$ thick and stored at $-20^{\circ} \mathrm{C}$. The black carrots were removed from the deep freeze in parts and dried for 48 hours under conditions of 5 mTorr pressure and ($80)^{\circ} \mathrm{C}$ with freeze dryer (Ilshin, Holland). Dried black carrots were triturated in the blender. Black carrot powders were packed under vacuum with low density polyethylene (LDPE) packages and stored at $-20^{\circ} \mathrm{C}$ in deep freeze until used.

\section{Ayran production}

Raw cow milk was standardized to $6 \%$ non-dry matter by using water. The ratios of black carrot in ayran were determined by preliminary tests. Milk was divided into four equal batches. One batch was taken as a control sample without black carrot addition (A). Other three batches of ayrans were manufactured by adding black carrot at the rates of $0.25 \%$ (B), $0.5 \%$ (C) and $1 \%(\mathrm{D})(\mathrm{v} / \mathrm{v})$. Then, all batches of milk were pasteurized at $90^{\circ} \mathrm{C}$ for 5 minutes, cooled to $46 \pm 1^{\circ} \mathrm{C}$ and inoculated of ayran starter culture $(25 \mathrm{mg} / \mathrm{L})$. The inoculated milk was incubated at $44 \pm 1^{\circ} \mathrm{C}$ until 4.6$4.7 \mathrm{pH}$. After incubation, ayran samples were cooled 
at $4^{\circ} \mathrm{C} \pm 1{ }^{\circ} \mathrm{C}$ and $0.5 \%$ salt was added. The mixture was homogenized and filled into $200 \mathrm{~g}$ of cups and stored at $4^{\circ} \mathrm{C} \pm 1^{\circ} \mathrm{C}$ overnight. The experiment was replicated three times on different days.

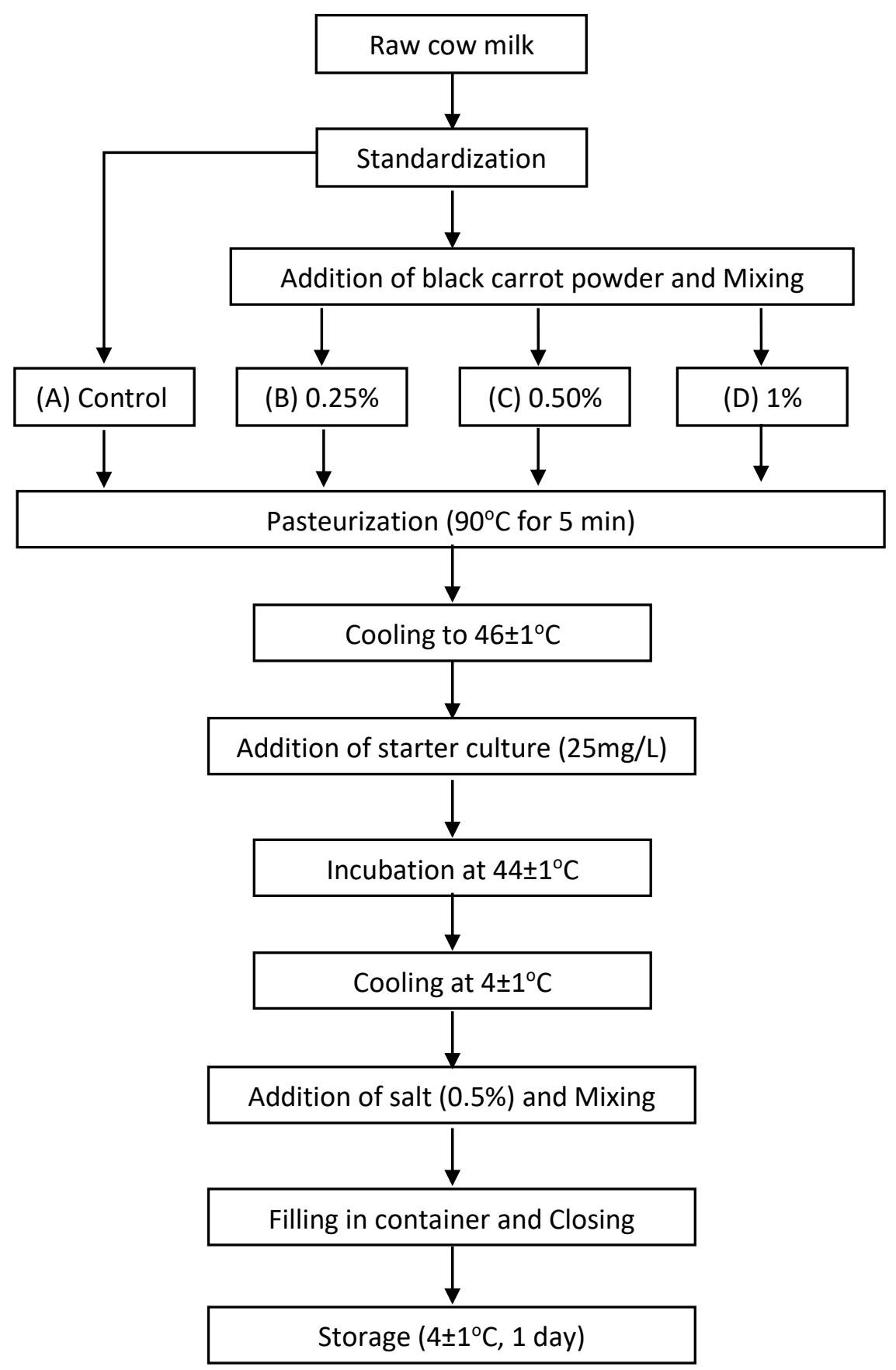

Figure 1: Ayran fortified with black carrot powder Şekil 1: Siyah havuç tozu ile zenginleştirilmiş ayran 


\section{Analysis}

The $\mathrm{pH}$ of the milk and ayran were measured using a digital $\mathrm{pH}$ meter (testo ${ }^{\circledR} 230$, Testo, GmbH \& Co, Germany). Titratable acidity (as percent lactic acid) was determined by alkali titration method (Anonymous, 1994). Total dry matter was determined by drying the samples in an oven at $100 \pm 5^{\circ} \mathrm{C}$ (IDF, 2010; Anonymous, 2003), fat content was determined by Gerber method (Anonymous, 2003; IDF, 2008), protein was determined by the total nitrogen method of Kjeldahl (AOAC, 1990, IDF, 1993) for milk and ayran samples. Salt contents of the ayran were determined according to Anonymous, 2003. The determination of antioxidant activity through DPPH (2,2 diphenyl 1- picpylhdrazyl) scavenging system was carried out according to the method of Matter et al., 2016 with some modifications. The antioxidant activities of ayran were determined spectrophotometrically according to the principle of detection of the change from the reaction of the DPPH active radical to the antioxidant substances found in the structure. The resultant change in the absorbent was observed at $517 \mathrm{~nm}$. Statistical analysis of ayran samples was interpreted using SPSS 18.0 statistical package program.

\section{Results}

The compositional values of cow milk that was used as raw material in the production of ayran fortified with black carrot powder are given in Table 1. The chemical composition of milk used for production of ayran samples found the following averages; $\mathrm{pH} 6.61$ \pm 0.08 , titratable acidity $0.17 \% \pm 0.02$, dry matter $11.96 \% \pm 0.26$, fat $3.50 \% \pm 0.89$ and protein $3.42 \pm$ 0.47 .

Table 1: The Composition of raw cow milk $(n=3)$

Tablo 1: Çiğ inek sütünün bileşimi $(n=3)$

\begin{tabular}{|lc|}
\hline Properties & Raw cow milk \\
\hline pH & $6.61 \pm 0.08$ \\
\hline Titration acidity (l.a. \%) & $0.17 \% \pm 0.02$ \\
\hline Dry matter (\%) & $11.96 \% \pm 0.26$ \\
\hline Fat (\%) & $3.50 \% \pm 0.89$ \\
\hline Protein (\%) & $3.42 \% \pm 0.47$ \\
\hline
\end{tabular}

Table 2: Composition of ayran fortified with black carrot powder $(n=3)$

Tablo 2: Siyah havuç tozu ile zenginleştirilmiş Ayranın bileşimi $(\mathrm{n}=3)$

\begin{tabular}{|lccccc|}
\hline Properties & \multicolumn{1}{c}{ A } & B & C & D & Codex \\
\hline pH & $4.68 \pm 0.15^{\mathrm{a}}$ & $4.49 \pm 0.09^{\mathrm{a}}$ & $4.42 \pm 0.04^{\mathrm{a}}$ & $4.54 \pm 0.09^{\mathrm{a}}$ & - \\
\hline Dry matter (\%) & $9.16 \pm 0.20^{\mathrm{a}}$ & $9.04 \pm 0.15^{\mathrm{a}}$ & $9.08 \pm 0.29^{\mathrm{a}}$ & $9.66 \pm 0.14^{\mathrm{a}}$ & - \\
\hline Fat (\%) & $1.95 \pm 0.09^{\mathrm{a}}$ & $1.88 \pm 0.11^{\mathrm{a}}$ & $1.90 \pm 0.06^{\mathrm{a}}$ & $1.92 \pm 0.11^{\mathrm{a}}$ & Full fat $\geq 1.8$ \\
\hline Protein (\%) & $3.64 \pm 0.28^{\mathrm{a}}$ & $3.31 \pm 0.02^{\mathrm{a}}$ & $3.81 \pm 0.34^{\mathrm{a}}$ & $4.06 \pm 0.19^{\mathrm{a}}$ & $\geq 2$ \\
\hline Salt (\%) & $0.83 \pm 0.02^{\mathrm{a}}$ & $0.85 \pm 0.03^{\mathrm{a}}$ & $0.90 \pm 0.07^{\mathrm{a}}$ & $0.92 \pm 0.08^{\mathrm{a}}$ & $\leq 1$ \\
\hline
\end{tabular}

A: Control ayran B: Ayran produced by adding $0.25 \%$ black carrot powder C: Ayran produced by adding

$0.5 \%$ black carrot powder D: Ayran produced by adding $1 \%$ black carrot powder

$\mathrm{a}, \mathrm{b}, \mathrm{c}$ Means in the same row with different letters were significantly different at $\mathrm{p}<0.05$ 
Composition of ayran fortified with black carrot powder is shown in Table 2. $\mathrm{pH}$, dry matter, fat, protein and salt contents of the ayran fortified with black carrot powder were not influenced by black carrot powder addition ( $\mathrm{p}>0.05)$.

Antioxidant activities at 0,5 and 20 minutes determined by DPPH method of ayran fortified with black carrot powder are given in Table 3. As the proportion of black carrots added in ayran production increased, all three of the antioxidant activities at 0,5 and 20 minutes increased and these increases in the 5th and 20th minutes were statistically significant ( $p$ $<0.05)$.

Table 3: Antioxidant activity of ayran fortified with black carrot powder $(n=3)$

Tablo 3: Siyah havuç tozu ile zenginleştirilmiş ayranın antioksidan aktivitesi $(\mathrm{n}=3)$

\begin{tabular}{|lccrc|} 
Antioxidant activity (\%) & \multicolumn{1}{c}{ A } & B & C & D \\
\hline O minute & $4.62 \pm 0.06^{\mathrm{a}}$ & $5.12 \pm 1.22^{\mathrm{a}}$ & $5.45 \pm 0.4^{\mathrm{a}}$ & $7.04 \pm 0.57^{\mathrm{a}}$ \\
\hline $\mathbf{5}$ minute & $5.88 \pm 0.16^{\mathrm{c}}$ & $11.93 \pm 1.88^{\mathrm{b}}$ & $12.15 \pm 0.6^{\mathrm{b}}$ & $19.90 \pm 1.07^{\mathrm{a}}$ \\
\hline $\mathbf{2 0}$ minute & $6.08 \pm 0.11^{\mathrm{c}}$ & $12.80 \pm 1.99^{\mathrm{b}}$ & $13.07 \pm 0.6^{\mathrm{b}}$ & $21.67 \pm 1.12^{\mathrm{a}}$ \\
\hline
\end{tabular}

A: Control ayran B: Ayran produced by adding $0.25 \%$ black carrot powder $\mathbf{C}$ : Ayran produced by adding $0.5 \%$ black carrot powder D: Ayran produced by adding $1 \%$ black carrot powder ${ }^{a, b, c}$ Means in the same row with different letters were significantly different at $\mathrm{p}<0.05$

\section{Discussion}

According to Turkish Food Codex Raw Milk and Heat Treated Drinking Milk Notification; titration acidity of raw cow milk in terms of lactic acid should be between $0.135-0.2 \%$, fat content should be at least $3.5 \%$ and protein content should be at least $2.8 \%$ (Anonymous, 2000). Titration acidity, fat and protein content of milk that was used in the production was appropriate for this scale.

The $\mathrm{pH}$ of ayran fortified with black carrot powder was in the ranged from $4.42 \%$ to $4.68 \%$ and the highest value was observed in control sample (A), followed by $\mathrm{D}, \mathrm{B}$ and $\mathrm{C}$, respectively. $\mathrm{pH}$ values were higher than the values reported by Atamer et al. (1999), Köksoy and Kılıç (2003), Koçak et al. (2006), Patır et al. (2006), Tonguç (2006), Şimsek et al. (2007), Tamuçay Özünlü and Koçak (2010b), Şanlı et al. (2011), Ayar and Burucu (2013), Erkaya et al. (2015) for ayran samples. Polat (2009) and Tamuçay Özünlü and Koçak (2010a) reported that $\mathrm{pH}$ values of production of ayran with using different cultures and samples of ayran ending the incubation at different $\mathrm{pH}$ were found as 4.36-4.46 and 3.99-4.52, respectively.

It was found that the dry matter values of the ayran were between 9.04 and 9.66 and the dry matter values of the ayran increased as the added black carrot powder amount increased. When the results of the study are compared to results of the previous study, it is found that dry matter values lower than the value reported by Tonguç (2006) for ayran produced using different combinations of probiotic bacteria. However, the values obtained in this study were determined to be higher than the values reported by Gülmez et al. (2003), Koçak et al (2006), Patır et al. (2006), Polat (2006).

The fat values of ayran samples ranged from $1.88 \%$ to $1.95 \%$. The highest amount of fat was determined in the ayran produced without the addition of black carrot powder (A), while the lowest amount of fat was determined in the ayran produced by adding $0.25 \%$ of black carrot powder (B). According to Turkish Food Codex Ferment Milk Products Notification, fat content of ayran should be at least $1.8 \%$ for full-fat ayran (Anonymous, 2009). It has been determined that ayran is full-fat according to the standard. Fat value of the ayran samples was higher than the values reported by Koçak et al. (2006) and Patır et al. (2006), lower than the values reported by Tonguç (2006), Polat (2009), Baruzzi et al. (2016).

As can be seen from Table 2, the highest protein value was found in the D ayran (4.06) which is produced without black carrot powder. This was followed by C ayran (3.81), A ayran (3.64) and B ayran 58 
(3.31), respectively. According to Turkish Food Codex Ferment Milk Products Notification, it has been stated that the protein value of ayran should be at least $2 \%$ (Anonymous, 2009). It has been determined that the protein values of the ayran produced are in accordance with the notification. The values of protein found in this study were higher than the results reported by Şen ve Küplülü (2004), Koçak et al. (2006), Tonguç (2006), Polat (2009), Baruzzi et al. (2016).

Salt values in the ayran samples varied from $0.83 \%$ to $0.92 \%$. The highest value of salt content was determined in the $\mathrm{D}$ ayran sample. The lowest salt content was determined in control sample. According to Turkish Food Codex Ferment Milk Products Notification, the salt content of ayran should be at most $1 \%$ (Anonymous, 2009). Salt value of ayran was found appropriate to the standard. Salt values of samples were higher than those of Koçak et al.'s (2006) reported but lower than those of Gülmez et al.'s (2003) reported.

The DPPH assay is simple method and to inform about the radical scavenging activity of the antioxidant substances present in the sample (Arslan and Özel, 2012). The lowest antioxidant activity has been detected in control samples, while the highest antioxidant activity was found in D ayran samples produced by adding $1 \%$ black carrot powder. Arslan and Özel (2012) reported that antioxidant value of yogurt produced with carrot juice and carrot juicegrape seed powder combination were determined as $0.17 \mu \mathrm{mol} \mathrm{TE} / \mathrm{g}$ dry weight and $0.24 \mu \mathrm{mol} \mathrm{TE} / \mathrm{g}$ dry weight, respectively. Altın et al. (2018) found that total antioxidant capacity of ayran with freeze dried cocoa hull waste extract (CHWPE), ayran with CHWPE powder, ayran with chitosan-coated liposomes containing CHWPE, ayran with spray-dried chitosancoated liposomal powder containing CHWPE were in the ranges $0.05-0.43 \mathrm{TEAC} \mathrm{mg} / \mathrm{mL}$.

\section{Conclusion}

In this study, ayran produced by adding $0.25 \%, 0.5 \%$ and $1 \%$ of freeze-dried black carrots into milk has the feature of being a new functional fermented dairy product. The composition properties of ayran were determined and it was determined that the ratio of dry matter, fat, protein and salt was not affected by the addition of black carrot powder. As the amount of dried black carrot powder added to the ayran increased, the antioxidant activity values were increased. In conclusion, black carrot may be used in ayran production successfully.

\section{Acknowledgements}

The authors express their gratitude to Cukurova University for financial support (Project No: FBA2017-5695)

This work is presented as an oral presentation at "2nd International Congress on Advances in Bioscience and Biotechnology (ICABB), June 26-30, 2018, Podgorica, Montenegro"

\section{References}

Altın, G., Gültekin-Özgüven, M., Ozcelik, B. (2018). Liposomal dispersion and powder systems for delivery of cocoa hull waste phenolics via ayran (drinking yoghurt): Comparative studies on in-vitro bioaccessibility and antioxidant capacity. Food Hydrocolloids, 81: 364-370. DOI: $10.1016 /$ j.foodhyd.2018.02.051

Anonymous (1994). TS 1018 Raw milk standard. Turkish Standards Institute. Necatibey Caddesi, 112. Bakanlıklar, Ankara, s.5.

Anonymous (2000). Turkish food codex, Communique on Raw Milk and Heat-Treated Drinking Milk Turkish food codex regulations, regulation No:2000/6. Ankara, Turkey: Republic of Turkey Ministry of Food, Agriculture and Livestock.

Anonymous (2003). TS 3810 Ayran. Turkish Standards Institute. Necatibey Caddesi, 112. Bakanlıklar, Ankara.

Anonymous (2009). Turkish food codex, Fermented milk products. Turkish food codex regulations, regulation No:2009/25. Ankara, Turkey: Republic of Turkey Ministry of Food, Agriculture and Livestock.

AOAC (1990). Official methods for analysis of official analytical chemists, 15th ed., Arlington, VA.

Arslan, S., Özel, S. (2012). Some properties of stirred yoghurt made with processes grape seed powder, carrot juice or a mixture of grape seed powder and carrot juice. Milchwissenschaft, 67 (3), 281-285.

Atamer, M., Gürsel, A., Tamuçay, B., Gençer, N., Yıldırım, G., Odabaşı, S., Karademir, E., Şenel, E., Kurdar, S. (1999). A study on the Utilization of pectin in manufacture of long-life ayran. Food, 24 (2), 119-126.

Ayar, A., Burucu, H. (2013). Effect of whey fractions on microbial and physicochemical properties of probiotic 
ayran (drinkable yogurt). Int Food Research J, 20(3), 1409-1415.

Baruzzi, F., Quintieri, L., Caputo, L., Cocconcelli, P., Borcakli, M., Owczarek, L., Jasinska, U.T., Skapska, S., Morea, M. (2016). Improvement of ayran quality by the selection of autochthonous microbial cultures. Food Microbiol, 60, 92-103. DOI:10.1016/j.fm.2016.07.001

Erkaya, T., Başlar, M., Şengül, M., Ertugay, M. F. (2015). Effect of thermosonication on physicochemical, microbiological and sensorial characteristics of ayran during storage. Ultrasonics Sonochemistry, 23, 406-412. DOI: 10.1016/j.ultsonch.2014.08.009

Gülmez , Güven, A., Sezer, Ç., Duman, B. (2003). Evaluation of microbiological and chemical quality of ayran samples marketed in Kars and Ankara cities in Turkey. Kafkas Univ. Vet. Med. J., 9 (1), 49-52.

IDF (2010). Milk, cream and evaporated milk-determination of total solids content (Reference method). IDF 021. Brussels: International Dairy Federation.

IDF (2008). Milk-determination of fat content. IDF 226. Brussels: International Dairy Federation.

IDF (1993). Milk-determination of titratable acidity. Brussels: International Dairy Federation.

Koçak, C., Avşar, T.K., Tamuçay, B. (2006). A comparative study on the production methods of ayran. Food, 31 (4), 225-231.

Koçak, C., Avşar, Y.K. (2010). Ayran: microbiology and technology. In: Yildiz, F. (Ed.), Development and Manufacture of Yogurt and Other Functional Dairy Products. CRC Press, Taylor \& Francis Group, Raton, FL, 123-141.

Kong, J.M., Chia L.S., Goh N.K., Chia T.F., Brouillard R. (2003). Analysis and Biological Activities of Anthocyanins, Phytochemistry, 64, 923-933. DOI:10.1016/S0031-9422(03)00438-2

Köksoy, A., Kılıç, M. (2003). Effects of water and salt level on rheological properties of ayran, a Turkish yoghurt drink. Int Dairy J,13, 835-839. DOI: 10.1016/S09586946(03)00103-1

Krokida, M.K., Philippopoulos C. (2006). Volatile of apples during air and freeze drying, J Food Eng, 73, 135141.

Matter, A.A., Eman, A.M.M, Nahla, S.Z. (2016). Fruit Flavored Yoghurt: Chemical, Functional and Rheological Properties. Int J Environ Agric Res, 5 (2), 57-66. ISSN:[2454-1850]

Özkan, M. 2009. Changes in Phenolic Substances and Antioxidants in the Production and Storage of Black Carrot Concentrate and the Relationship Between These Changes and Antioxidant Activity. Ankara: Ankara Üniversity Scientific Research Project Final Report.

Patır, B., Öksüztepe, G., Şeker, P., Dikici, A. (2006). Microbiological and Chemical Quality of Packaged or Nonpackaged ayran marketed in Elazığ. $F U J$ Health Sci, 20 (5), 357-363.

Polat, S., 2009. Determination of some characteristics ayran production with using different cultures. Adana, Turkey,
Thesis of MSc, Cukurova University Institue of Natural and Applied Sciences, Food Engineering.

Şanlı, T., Sezgin, E., Şenel, E., Mehlika, B. (2011). The effect of transglutaminase on some

physicochemical and sensory properties of the Turkish drinking yoghurt ayran. Int J Dairy Technol, 66 (3), 410416. DOI: 10.1111/1471-0307.12045

Şen, E., Küplülü, Ö. (2004). Determination of Agreement to Turkish Food Codex of Unpackaged ayran Consumed in Ankara. Etlik Vet Microbiol J, 15 (1-2), 55-60.

Sharma, K.D., Karki S., Thakur N.S., Attri S. (2012), Chemical composition, functional properties and processing of carrot - a review, J Food Sci Technol, 49, 22-32. DOI: 10.1007/s13197-011-0310-7

Şimsek, B., Sagdic, O., Ozcelik, S. (2007). Survival of O157:H7 during the storage Escherichia coli of ayran produced with different spices. J Food Eng, 78, 676-680. DOI: 10.1016/j.jfoodeng.2005.11.005

Tamuçay Özünlü, B., Koçak, C. (2010a). Effect of ending the incubationa at different $\mathrm{pH}$ 's on quality of ayran. Food, 35(2), 113-119.

Tamuçay Özünlü, B., Koçak, C. (2010b). The effects of Different heat treatments of milk on Quality of ayran. Food, 35 (5), 355-362.

Tonguç, I.E. (2006). A Study on ayran Production Using Probiotic Bacteria. İzmir, Turkey, Thesis of MSc, Ege University Institue of Natural and Applied Sciences.

Uyan, S.E., Baysal T., Yurdagel Ü., EI S.N. (2004). Effects of drying process on antioxidant activity of purple carrots, Nahrung/Food, 48, 57-60. DOI: 10.1002/food.200300373

Witrowa-Rajchert, D., Bawol, A., Czapski, J., Kidon, M. (2009). Studies on Drying of Purple Carrot Roots. Dry Technol, 27: 1325-1331. DOI: 10.1080/07373930903226043

Yıldız, F. (2010). Overview of yogurt and other fermented dairy products. In: Yildiz, F. (Ed.), Development and Manufacture of Yogurt and Other Functional Dairy Products. CRC Press, Taylor \& Francis Group, Raton, FL, 1-122. 